\title{
Gino Strada (1948-2021)
}

\author{
Giorgio Monti
}

Medicina D'Urgenza e Pronto Soccorso, Ospedale Sant'Orsola-Malpighi, Bologna, Italy

What should be an Emergency Physician? A doctor and a man accustomed to extreme and courageous choices, able to decide quickly, capable of brilliant intuitions and strong standpoints, guided by great determination, self-awareness, enlightened by deep convictions and clear ideas, and an empathy that allows him to never lose his humanity and always know which side to stand on... I worked and had the privilege of being a friend of a great doctor with these characteristics. Gino Strada, for all DOCTORGINO (yes, all attached), was a man with a great sense of irony, and intuitions so strong to seem crazy, to which he added the ability to make them happen. At his home in Milan talking about Afghanistan or in the evenings shared in the missions he said to me: "war is a horror," "health and quality of care are everyone's right." In Sierra Leone he claimed: "we bring quality medicine where there is neither quality nor equality," "a hospital is good when you are willing to have your child treated there" and helped me to run the only intensive care unit for Ebola patients in Africa; in Sudan: "we make a hospital that is beautifully clean and of absolute quality" during the war in the Central African Republic: "we treat everyone without asking anyone which side they are on;" and in the refugee camps of Kurdistan: "the children of our hospitals are the victims of the war of the grown-ups." During the speech of thanks for the Right Livelihood Award in Stockholm (which has, to date, recognised the courageous and visionary achievements of 182 change-makers from 72 countries) he said: "I am a surgeon and I have seen the wounded and dead of various conflicts in Asia, Africa, the Middle East, Latin America and Europe and I have operated on thousands of people, injured by bullets, bomb fragments or missiles. $90 \%$ of the victims were civilians $1 / 3$ of them children. So is this "the enemy"? Who pays the price of war? ... The right to receive adequate medical care is a universal right ... this is how the idea of establishing centres of excellence in Africa was born. EMERGENCY is still needed because EMERGENCY has shown that there are no impossible bets. We know we're just planting seeds, we don't know if even one of these seeds will become a tree... but at least we tried. A hospital that heals well and for free on a continent is like a drop in an ocean ... I hope this can be an

Correspondence: Giorgio Monti, Medicina D’Urgenza e Pronto Soccorso, Ospedale Sant'Orsola-Malpighi, Via Giuseppe Massarenti 11, 40138 Bologna, Italy.

E-mail: giorgio.monti@aosp.bo.it

Key words: Gino Strada; Emergency; emergency medicine

Received for publication: 15 September 2021.

Accepted for publication: 15 September 2021.

This work is licensed under a Creative Commons Attribution 4.0 License (by-nc 4.0).

OCopyright: the Author(s), 2021

Licensee PAGEPress, Italy

Emergency Care Journal 2021; 17:10135

doi:10.4081/ecj.2021.10135 example to start positive change Working together for a world without war is the best thing we can do for future generations...

You can feel proud of being a doctor he made you feel proud of a Human Being... These are the memories that I shared with a great Man a great Doctor. I am an Emergency physician ... I am an EMERGENCY's physician."

Gino Strada was born in Sesto San Giovanni (Milan, Italy) on April $21^{\text {st }}$, 1948. After graduating in Medicine and Surgery, he specializes (1978) in Emergency Surgery at the State University of Milan; then he moved for 4 years at the Universities of Stanford and Pittsburgh where he deals with heart and lung transplant surgery. Subsequently he carries out training periods at Harefleld Hospital (England) Groote Schuur Hospital (Cape Town South Africa). From 1988 he became a "war surgeon" and worked for the ICRC International Committee of Red Cross in Geneva in Pakistan, Ethiopia, Thailand, Afghanistan, Peru, Djibouti Somalia and Bosnia, until 1994 when with some colleagues, some friends and his wife Teresa Sarti he founded EMERGENCY, an independent and neutral association created to deliver high quality and free surgical medical care to the victims of wars, landmines and poverty. The first project is in Rwanda, during the genocide, then in Cambodia for years. In 1999, the first surgical centre in Anabah opens in the Panishjr valley in Afghanistan. It will remain operate there for 7 years, while other hospitals in Kabul and Laskargah were opened. Today Emergency is in Afghanistan with 3 hospitals, 1 maternity center and 44 first aid posts. The "Salam center" opened 2005 in Khartoum, in Sudan, the first totally free heart surgery center in Africa. Paediatric hospitals were then opened in Iraq, in Kurdistan, and in the Central African Republic. In 2011 a surgical and paediatric hospital was inaugurated in Freetown, Sierra Leone, and in 2014 an intensive care unit was opened to fight the Ebola epidemic. Lastly, he opened a children's hospital in Entebbe, Uganda, in 2021.

\section{Awards and acknowledgments}

2001 Prize Colombe d'Oro per la Pace (Golden Doves for Peace)

Ricerche internazionali Archivio disarmo Roma

2003 Prize Antonio Feltrinelli Accademia Nazionale de Lincei

2006 PHD in Humane Letters Colorado College di Colorado Springs, Colorado

2015 Right Livelihood Award (considered the "alternative Nobel Peace Prize") Stockholm

2017 Prize Sunhak for Peace, South Korea

\author{
Books (main) \\ Pappagalli Verdi, diario di un chirurgo di guerra (1999). \\ Giangiacomo Feltrinelli Ed. \\ Buskashi, viaggio dentro la guerra (2002). Giangiacomo \\ Feltrinelli Ed. \\ Zona rossa, con Roberto Satolli (2014). Giangiacomo
} Feltrinelli Ed. 